\title{
Molecular Responses to Abscisic Acid and Stress Are Conserved between Moss and Cereals
}

\author{
Celia D. Knight, ${ }^{a, 1}$ Amita Sehgal, ${ }^{a}$ Kamaljit Atwal, ${ }^{a}$ John C. Wallace, ${ }^{a, 2}$ David J. Cove, ${ }^{a}$ David Coates, ${ }^{b}$ \\ Ralph S. Quatrano, ${ }^{c}$ Sultan Bahadur, ${ }^{a}$ Peter G. Stockley, ${ }^{a}$ and Andrew C. Cuming ${ }^{a}$ \\ a Department of Genetics, The University of Leeds, Leeds LS2 9JT, United Kingdom \\ b Department of Pure and Applied Biology, The University of Leeds, Leeds LS2 9JT, United Kingdom \\ c Department of Biology, University of North Carolina, Chapel Hill, North Carolina 27599-3280
}

Promoter elements from the wheat Em gene have been characterized. These elements are inducible by abscisic acid (ABA) and by osmotic stress. In this study, we demonstrated that the same promoter elements function in a distantly related plant species, the moss Physcomitrella patens. Transient and stable expression of the $\beta$-glucuronidase reporter gene was used to determine that the heterologous wheat promoter also responds to osmotic stress and ABA in moss. Mutational analysis of the promoter indicated that the mechanism of gene regulation is conserved in both species. Gel retardation and DNase I footprint analyses were conducted to characterize further the interaction of moss transcription factors with the Em promoter. In addition, the synthesis of stress-related polypeptides in moss was observed. The evolutionary significance of these data and the potential for studying the entire ABA perception-response pathway in moss are discussed.

\section{INTRODUCTION}

Due to their sedentary mode of life, plants are exposed to widely fluctuating environments and consequently have evolved mechanisms to limit the physiological damage that would otherwise result from these conditions. Water deficit stress is one such environmental factor that plants must overcome to survive. In higher plants, adaptation to water stress ranges from rapid physiological responses, such as stomatal closure, to elicitation of new gene expression. Common to many of these responses is the growth regulator abscisic acid (ABA), which has been identified as an agent in the stress perceptionresponse pathway (Rock and Quatrano, 1994, 1995). The application of both osmotic stress and ABA induces the expression of a characteristic subset of genes encoding the so-called ABAresponsive Rab or dehydrin proteins (Close et al., 1989; Skriver and Mundy, 1990; Chandler and Robertson, 1994). These proteins accumulate both in vegetative tissues under stress and in later stages of embryogenesis (designated Lea proteins), a process regulated by $A B A$ which culminates naturally in the formation of a highly dehydrated propagule (Dure et al., 1989; Piatkowski et al., 1990). Studies with wheat embryos, focusing on the expression of genes encoding the prominent Em protein, indicate that $\mathrm{ABA}$ and osmotic stress act through a common pathway to induce transcription (Marcotte et al., 1988; Guiltinan et al., 1990; Morris et al., 1990).

1 To whom correspondence should be addressed.

${ }^{2}$ Current address: Department of Biology, Bucknell University, Lewisburg, PA 17837.
In contrast, lower plants lack many of the specialized structures that characterize higher plants' adaptations to the terrestrial environment, for example, cuticles and ramifying root systems that enable the scavenging of soil water. However, such plants often exhibit a remarkable ability to withstand dehydration, as exemplified by the moss Tortula ruralis, studied extensively by Bewley and his colleagues (reviewed in Bewley and Oliver, 1992). In this species, the onset of dehydration does not appear to trigger changes in gene expression. Instead, a rehydration-dependent repair system has been proposed to account for its desiccation hardiness (Oliver, 1991; Scott and Oliver, 1994).

We examined the molecular responses of the moss Physcomitrella patens both to osmotic stress and to the application of ABA. In contrast to the responses reported for Tortula, we found a remarkable conservation of function of the stress response mechanism between this lower plant and higher plants.

\section{RESULTS}

\section{Synthesis of Stress Response Proteins}

When higher plant tissues are subjected to osmotic stress or are treated with ABA, a novel set of Rab, or dehydrin, proteins accumulates. These proteins are typified by a high degree of 


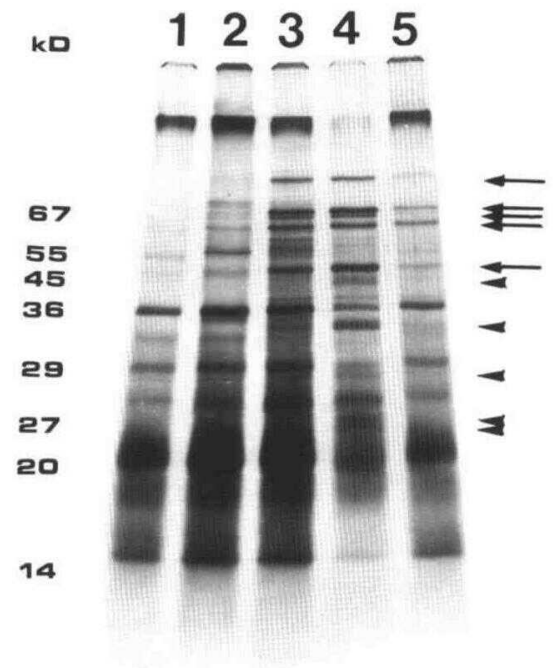

Figure 1. Polyacrylamide Gel Showing Heat-Stable Polypeptides Extracted from Protonemal Tissue.

Tissue was labeled with ${ }^{35} \mathrm{~S}$-methionine following incubation for $6 \mathrm{hr}$ in media supplemented with mannitol or ABA. Lane 1 contains water; lane 2, 0.27 M mannitol; lane 3, 0.55 M mannitol; lane 4, 0.83 M mannitol; lane $5,10^{-4} \mathrm{M}$ ABA. Each track contained $10^{5} \mathrm{cpm}$ of incorporated radioactivity. The migration of molecular mass standards is indicated at left. The arrows indicate the position of polypeptides synthesized strongly in the presence of both mannitol and ABA; the arrowheads denote the position of polypeptides induced strongly by mannitol treatment only.

hydrophilicity, enabling them to remain in solution even when protein extracts are boiled (Jacobsen and Shaw, 1989). In this study, protonemal tissue of $P$. patens was labeled with ${ }^{35} \mathrm{~S}$ methionine in the presence of $A B A$ or following osmotic stress induced by incubation with mannitol. Polyacrylamide gel analysis demonstrated the appearance of a subset of newly synthesized boiling-stable polypeptides, including several with molecular masses between 60 and $80 \mathrm{kD}$ (Figure 1). Under conditions of relatively extreme stress induced by treatment with $0.83 \mathrm{M}$ mannitol or in the presence of $10^{-4} \mathrm{M} \mathrm{ABA}$, the relative synthesis of the constitutive boiling-stable proteins was markedly decreased (Figure 1, lanes 4 and 5). Similar patterns of polypeptide synthesis were observed in response to osmotic stress and to $\mathrm{ABA}$, although additional osmotic stress-specific products of approximately 25 to 28,35 , and $40 \mathrm{kD}$ were identified (Figure 1, lane 4).

\section{In Vivo Expression of a Heterologous ABA-Inducible Promoter}

ABA-inducible wheat Em promoter- $\beta$-glucuronidase (GUS) reporter gene fusions were introduced into $P$. patens to determine whether the similarity between the hormone response pathways extended to the level of transcriptional regulation.
Plasmid DNA was delivered to protonemal tissue by microprojectile bombardment or to protoplasts by polyethylene glycol-mediated direct uptake; transient expression of the reporter gene was measured fluorometrically. Plasmid pBM113kp is composed of a 650-bp Em promoter fragment fused to the GUS gene (Marcotte et al., 1988). Plasmid pBM200.15 contains a $5^{\prime}$ deleted promoter of 385 bp that includes the ABA response element (ABRE). Following bombardment, plasmids resulted in induction of gene expression in moss in the presence of $10^{-4} \mathrm{M} \mathrm{ABA}$ (Table 1). This concentration of ABA has been shown to induce maximal expression of the Em-GUS reporter gene in rice protoplasts (Marcotte et al., 1988) and to be the optimum for inducing expression in moss (Sehgal, 1994). Tissue was also bombarded with plasmid pBM1a $\Delta, a$ promoter variant that differed from pBM200.15 only by a 2-bp substitution in the Emla sequence within the ABRE. Table 1 shows that $A B A$ inducibility was effectively abolished by this minimal mutation.

When pBM113kp was introduced into protoplasts, a higher mean level of transient activity was obtained after treatment with ABA (Table 2). Because these data also included a higher standard error, the activities from six independent experiments were analyzed. Table 3 shows that the activities vary widely among experiments but that within an experiment, the ratio of activities indicates that in five of six experiments, a severalfold increase in GUS activity occurs in response to the inductive treatment. The Em promoter in plasmid pBM113kp therefore appears induced by $A B A$ in protoplasts as well as in protonemal tissue, but there is greater variation among protoplast experiments. This variation might be due to a difference in competence of the protoplasts. The effect of treating protoplasts with water alone could not be measured because $0.44 \mathrm{M}$ mannitol was necessarily present in the medium to maintain high osmolarity. However, the four fold increase in GUS activity when ABA was added to the protoplasts suggests that the promoter was responding similarly to the bombarded tissue

Table 1. Transient Expression of Em-GUS and Promoter Deletions

\begin{tabular}{|c|c|c|c|}
\hline \multirow[b]{2}{*}{ Plasmid } & \multicolumn{3}{|c|}{ GUS Activity } \\
\hline & $+\mathrm{ABA}$ & $+\mathrm{H}_{2} \mathrm{O}$ & ABA: $\mathrm{H}_{2} \mathrm{O}$ \\
\hline pBM113kp & $4.3 \pm 1.7$ & $0.4 \pm 0.3$ & 10.7 \\
\hline pBM200.15 & $5.7 \pm 2.8$ & $0.7 \pm 0.3$ & 8.2 \\
\hline pBM1aA & $1.9 \pm 1.1$ & $1.3 \pm 1.0$ & 1.5 \\
\hline
\end{tabular}

The transient expression assay was conducted after microprojectile bombardment of protonemal tissue with plasmids pBM113kp, pBM200.15, and pBM1a $\Delta$. GUS activity (nanomoles of 4-methylumbelliferone per microgram of protein per hour) was measured fluorometrically following $48 \mathrm{hr}$ of treatment with $(+) 10^{-4} \mathrm{M} \mathrm{ABA}$ or water. Data are the means and standard errors of at least three independent experiments. The ratios of activity are calculated using the average values. 
Table 2. Stable and Transient Expression of Em-GUS Induced by ABA and Mannitol

\begin{tabular}{lccccc}
\hline & \multicolumn{3}{l}{ GUS Activity } & & \\
\cline { 2 - 6 } Treatment $^{\mathrm{a}}$ & $+\mathrm{ABA}$ & $+\mathrm{H}_{2} \mathrm{O}$ & + Mannitol & ABA: $\mathrm{H}_{2} \mathrm{O}$ & ABA:Mannitol \\
\hline 1 & $4.3 \pm 1.7$ & $0.4 \pm 0.3$ & $1.0 \pm 0.1$ & 10.7 & 4.3 \\
2 & $1882 \pm 1638$ & $-\mathrm{b}$ & $477 \pm 359$ & $-\mathrm{b}$ & 3.9 \\
3 & $32,837 \pm 2088$ & $1179 \pm 165$ & $5566 \pm 185$ & 27.8 & 5.9 \\
\hline
\end{tabular}

a Treatment 1 was the transient expression assay following microprojectile bombardment. pBM113kp was introduced into tissue, and the tissue was treated immediately with (+) either $10^{-4} \mathrm{M}$ ABA, $0.44 \mathrm{M}$ mannitol, or water for $48 \mathrm{hr}$. Treatment 2 was the transient expression assay following direct uptake of DNA by protoplasts. pBM113kp was introduced into protoplasts, and the protoplasts were then treated with either $10^{-4} \mathrm{M} \mathrm{ABA}$ or water for $48 \mathrm{hr}$ after $24 \mathrm{hr}$ of incubation in the light. Values for the water control for treatment 2 are given under + Mannitol because of the presence of mannitol in the protoplast medium (see text). Treatment 3 was the measurement of GUS expression in the transgenic plant. pLUG2 was introduced by microprojectile bombardment. Following selection of a stable transformant, protonemal tissue was grown on basal medium before transfer to medium containing $10^{-4} \mathrm{M} \mathrm{ABA}, 0.44 \mathrm{M}$ mannitol, or water for $24 \mathrm{hr}$. Proteins were extracted, and GUS activity (nanomoles of 4-methylumbelliferone per microgram of protein per hour) was measured fluorometrically as described in the text. Data are the means and standard errors of at least three independent experiments with the exception of treatment 2. This treatment included data from six independent experiments, and the individual data for these treatments are shown in Table 3. The ratios of activity are calculated using the average values.

$b_{-}$, not tested.

treated with mannitol alone. Because $0.44 \mathrm{M}$ mannitol was sufficient to induce low levels of synthesis of osmotic stressrelated polypeptides in intact tissue (Figure 1), it seems probable that the results of all transient assays using protoplasts included osmotic stress-induced gene activity. Table 2 thus demonstrates that the wheat $E m$ promoter was inducible in moss by osmotic stress alone but to a lesser degree than by $10^{-4} \mathrm{M} \mathrm{ABA}$.

Reporter gene expression may also be monitored in transgenic moss. $P$. patens was transformed by plasmid pLUG2, which contains both the full-length Em-GUS reporter gene from pBM113kp and the selectable marker gene neomycin phosphotransferase II (nptII), and transformants were selected on medium containing the aminoglycoside analog Geneticin. Regenerated plants were treated with ABA or water for $24 \mathrm{hr}$, and GUS expression was observed visually by staining with 5-bromo-4-chloro-3-indolyl $\beta$-D-glucuronide. The pattern of the histochemical stain is shown in Figure 2. All cells showed an intense blue stain after ABA treatment (Figure 2A), whereas the cells in the water-treated control were unstained or stained only weakly (Figure 2B). The transgenic strain was also used to confirm the inductive effect of mannitol by growing tissues for 4 days on basal medium and then transferring to medium containing either $10^{-4} \mathrm{M} \mathrm{ABA}$ or $0.44 \mathrm{M}$ mannitol. GUS activity for the transgenic strain reported in Table 2 agrees with that of the transient expression assays and confirms that mannitol acts as an osmotic stress agent to induce gene activity.

\section{Identification of Proteins with DNA Binding Activity}

In wheat, a basic leucine zipper transcription factor (EmBP-1) has been shown to interact specifically with the ABRE (Guiltinan et al., 1990). To examine whether ABA induction in moss was due to an EmBP-1 homolog, DNA binding experiments were performed. Moss nuclear protein extracts were used in gel retardation assays with radiolabeled DNA probes containing the wheat ABRE. The results are shown in Figure 3A. In reaction mixtures containing increasing amounts of moss nuclear extract, increasing amounts of at least three retarded complexes were obtained. Binding was sequence specific as determined by competition experiments with unlabeled wheat ABRE fragments and a variant having the same 2-bp substitution in the high-affinity Em1a site of the ABRE as the promoter construct $\mathrm{pBM} 1 \mathrm{a} \Delta$, which did not function. DNase I footprinting was used to confirm that a moss nuclear factor bound specifically to the Em1a site. Figure $3 B$ shows that a 10-bp region of DNA overlapping part of the Em1a site, defined in cereals by methylation interference (Guiltinan et al., 1990), was footprinted by the moss nuclear extract. In an attempt to fractionate the nuclear extract, we found that the DNA binding activity would survive brief incubation at $90^{\circ} \mathrm{C}$. Under this condition, the majority of nuclear proteins precipitated (data not

Table 3. GUS Activity for the Six Independent Experiments Whose Mean Values Are Shown in Treatment 2 of Table 2

\begin{tabular}{llll}
\hline Experiment & + ABA & + Mannitol & ABA: Mannitol \\
\hline 1 & 2637 & 647 & 4.1 \\
2 & 2251 & 760 & 3.0 \\
3 & 4590 & 645 & 7.1 \\
4 & 1135 & 775 & 1.5 \\
5 & 504 & 23 & 21.9 \\
6 & 172 & 15 & 11.5 \\
\hline
\end{tabular}

Treatment and conditions are as given in Table 2. GUS activity is given as nanomoles of 4-methylumbelliferone per microgram of protein per hour. 


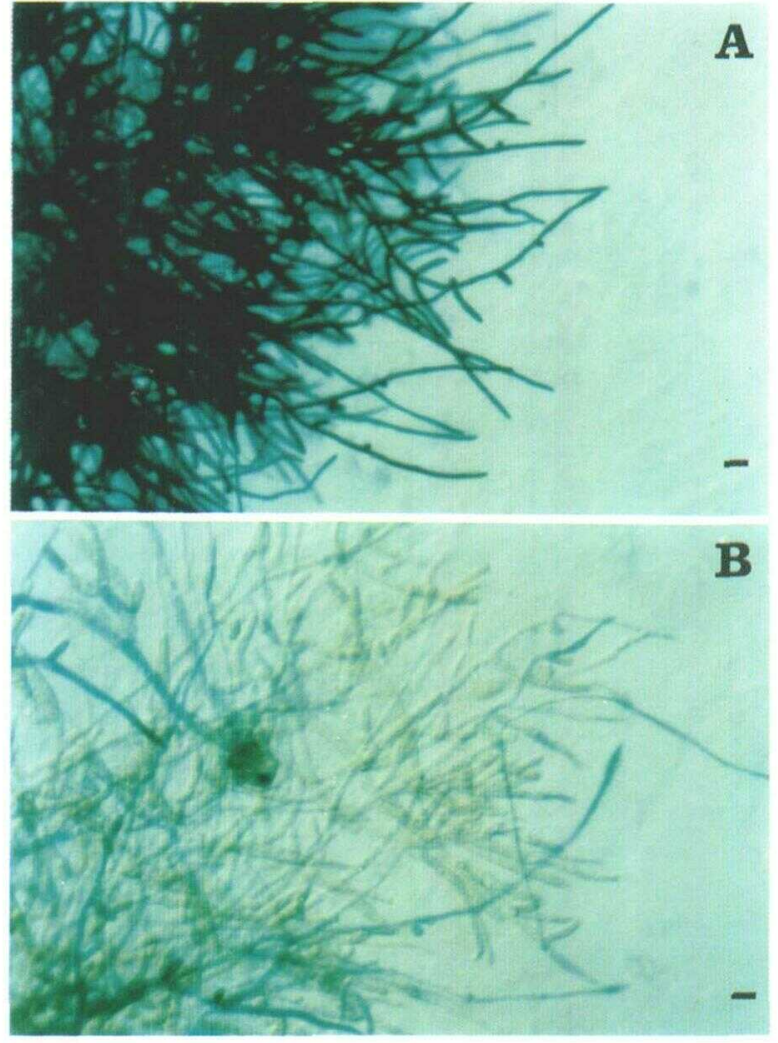

Figure 2. Pattern of GUS Expression in 10-Day Protonemal Tissue of Transgenic Moss Containing the 650-bp Em-GUS Fusion.

Tissue was stained with 5-bromo-4-chloro-3-indolyl $\beta$-D-glucuronide.

(A) Tissue treated with $10^{-4} \mathrm{M}$ ABA.

(B) Tissue treated with water.

Bars $=100 \mu \mathrm{m}$.

shown). The moss Em binding protein activity therefore seems to be heat stable.

\section{DISCUSSION}

In higher plants, the best characterized response to ABA is stomatal closure. Although mosses have stomata that respond to ABA (Garner and Paollilo, 1973), these are confined to the sporophyte, which was not investigated in this study. In contrast to the plant hormones cytokinin and auxin, which have been shown to play key roles in the developmental program of mosses (reviewed in Cove, 1992; Cove and Knight, 1993), the role of $A B A$ has received little attention. Three reports associate $A B A$ with water stress responses in mosses. Werner et al. (1991) reported that ABA levels increase in Funaria hygrometrica following slow dehydration and that this moss is then more tolerant to subsequent dehydration. Furthermore,
$\mathbf{A}$

1234567

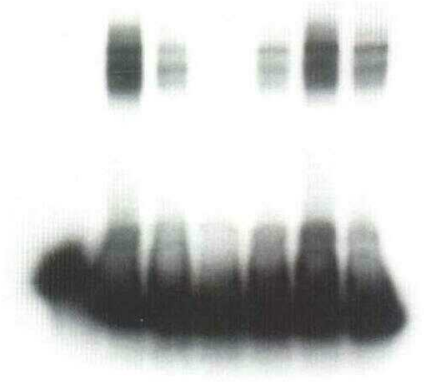

B

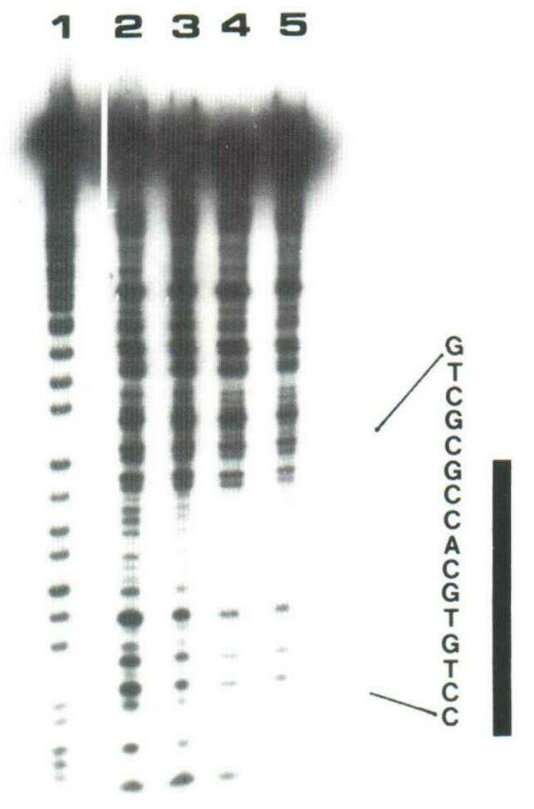

Figure 3. In Vitro Analysis of ABRE-Moss Protein Interactions.

(A) Polyacrylamide gel demonstrating specific retardation of labeled DNA by nuclear proteins. One nanogram of the labeled ABRE fragment (10 to $15 \times 10^{3} \mathrm{cpm}$ ) was incubated with the following nuclear proteins: lane 1, no protein; lane $2,7 \mu \mathrm{g}$ of nuclear protein extract; lane $3,7 \mu \mathrm{g}$ of extract plus $5 \mathrm{ng}$ of unlabeled wild-type probe (CACGTG); lane $4,7 \mu \mathrm{g}$ of extract plus $50 \mathrm{ng}$ of unlabeled wild-type probe; lane $5,7 \mu \mathrm{g}$ of extract plus $50 \mathrm{ng}$ of unlabeled mutant probe (CCCGGG); lane $6,7 \mu \mathrm{g}$ of extract plus $5 \mathrm{ng}$ of unlabeled mutant probe; lane 7 , $7 \mu \mathrm{g}$ of extract plus $25 \mathrm{ng}$ of unlabeled mutant probe.

(B) Sequencing gel demonstrating protection from DNase I digestion by moss nuclear protein extract. Lane $1, \mathrm{G}+\mathrm{A}$ ladder; lane 2, no protein; lane 3, $5 \mu \mathrm{g}$ of extract; lane 4, $7 \mu \mathrm{g}$ of extract; lane $5,10 \mu \mathrm{g}$ of extract. The sequence of the wild-type DNA strand is shown alongside the gel indicating the region footprinted by the moss nuclear extract and the extent of the Emla site defined in cereals (black bar). 
ABA application alone can induce desiccation tolerance. It has been shown that new proteins accumulate in $F$. hygrometrica following ABA treatments (Bopp and Werner, 1993; Werner and Bopp, 1993). Goode et al. (1992) reported the acquisition of similar desiccation tolerance in a number of mosses, including $P$ patens, following $A B A$ application.

In this study, we demonstrated that in $P$. patens the synthesis of specific proteins is elicited by ABA and by treatment with mannitol. In higher plants, osmotic stress and $A B A$ induce the synthesis of a shared set of low molecular mass (18 to $40 \mathrm{kD}$ ) heat-stable proteins (Close et al., 1989; Piatkowski et al., 1990; Robertson and Chandler, 1992; Butler and Cuming, 1993). In $P$. patens, the molecular masses of the heat-stable polypeptides are relatively high (Figure 1), and they do not cross-react with antibodies raised against the cereal $R a b$ or dehydrin proteins (A.C. Cuming, unpublished data).

More significantly, we found a remarkable degree of similarity between the molecular responses of mosses and cereals; the same cis-acting promoter sequences were recognized in both wheat and moss. A 2-bp substitution in the Em1a site, which is sufficient to eliminate ABA-induced GUS activity in rice protoplasts (Marcotte et al., 1988), has the same effect in moss protoplasts. The strength of the promoter is clearly illustrated by the intensity of histochemical staining in Figure $2 \mathrm{~A}$ and the high expression levels given in Table 2. A low level of expression was manifested in a few cells of the water-treated $P$. patens control (Figure $2 \mathrm{~B}$ ); this may have been due to the presence of endogenous $A B A$.

The behavior of the moss nuclear extract in competition assays is consistent with the presence of an EmBP-1 homolog in moss (Devos et al., 1991). However, we have been unable to detect DNA homology following DNA gel blot hybridization analysis of moss genomic DNA using the wheat EmBP-1 CDNA under nonstringent hybridization conditions ( $S$. Bahadur, unpublished data). The fact that the DNA binding activity is relatively heat stable assists in its purification and molecular characterization.

In conclusion, we showed that the moss $P$. patens exhibits $A B A-$ and osmotic stress-induced changes in gene expression and that, at least in part, ABA-regulated gene expression operates in a manner analogous to that observed in wheat. The wheat $E m$ promoter is the strongest and best characterized ABA-inducible plant promoter reported to date. Many molecular tools, therefore, exist to extend this characterization in moss and generate data of evolutionary interest, given the taxonomic distance between the two plant groups. More crucially, the experimental tractability of $P$. patens as a model for the study of plant development offers enormous potential for the study of the ABA signal-perception pathway (Knight, 1994). For example, transgenic $P$. patens containing the apoaequorin gene (Russell, 1993) will enable researchers to investigate changes in calcium levels in response to ABA. Perhaps the overriding attribute, however, is that ABA-regulated gene expression is manifest in single cells. These include protoplasts, which are easy to obtain in large quantities and to manipulate, as well as protonemal cells, which are shown in
Figure 2. An opportunity is thus presented to study the biochemistry of the entire ABA perception and transduction pathway.

\section{METHODS}

\section{Physcomitrella patens Culture}

The Gransden wild-type isolate (Schaefer et al., 1991) was used in this study. Plant cultures were maintained and subcultured as described by Ashton and Cove (1977). All experiments were initiated using plant tissue grown for 7 days under continuous light on agar medium overlaid with cellophane (Grimsley et al., 1977).

\section{Plasmids}

Plasmids pBM113kp, pBM200.15, pMG76.155, pBM233.3, and pBM1aA were constructed by Marcotte et al. (1989). Plasmid pLUG2 was constructed by insertion of the $1.7-\mathrm{kb}$ EcoRI fragment containing the $35 \mathrm{~S}$ cauliflower mosaic virus-neomycin phosphotransferase II (nptII) cassette from plasmid pHP23 (Paszkowski et al., 1988) into the single site of pBM113kp (Marcotte et al., 1988).

\section{Protein Analysis}

For labeling experiments, 2-cm squares of cellophane (W. Canning, Bristol, UK) bearing protonemal tissue were transferred to two layers of filter paper (No. 3MM, Whatman, Maidstone, Kent, UK), soaked with water, abscisic acid (ABA), or mannitol at the concentrations indicated in the text, and incubated in sealed Petri dishes. Incubation was for $6 \mathrm{hr}$ at $25^{\circ} \mathrm{C}$ in the light prior to pulse labeling. For labeling, tissue was transferred onto a $50-\mu \mathrm{L}$ droplet of ${ }^{35} \mathrm{~S}$-methionine in incubation medium $(880 \mu \mathrm{Ci} / \mathrm{mL}$ ) that was placed on a square of Parafilm (Fisons, Loughborough, UK) that overlaid two layers of Whatman filter paper No. 3MM soaked with water to maintain a water-saturated atmosphere within the Petri dish during the incubation period. After $1.5 \mathrm{hr}$, tissue was ground with a mortar and pestle and homogenized with acidwashed sand in extraction buffer $(25 \mathrm{mM}$ Tris- $\mathrm{Cl}, \mathrm{pH} 7.5,50 \mathrm{mM} \mathrm{KCl}$, $5 \mathrm{mM} \mathrm{MgCl}_{2}, 5 \mathrm{mM} \beta$-mercaptoethanol). The homogenate was clarified by centrifugation at $12,000 \mathrm{~g}$ for $10 \mathrm{~min}$, and the supernatant was stored at $-20^{\circ} \mathrm{C}$. For analysis of heat-stable proteins, aliquots of supernatant were boiled for $10 \mathrm{~min}$. Coagulated proteins were removed by centrifugation ( $10 \mathrm{~min}$ at $12,000 \mathrm{~g}$, twice), and the residual supernatant was used for electrophoresis. Labeled proteins were analyzed on SDS-polyacrylamide gels containing a 10 to $30 \%(\mathrm{w} / \mathrm{v})$ linear gradient of acrylamide and detected by fluorographic exposure of the dried gel.

\section{Transient Expression Assays}

Plasmids were purified by standard procedures (Sambrook et al., 1989). Protoplast transformation was performed according to Schaefer et al. (1991). Following DNA uptake, protoplasts were incubated in the light in regeneration medium for $24 \mathrm{hr}$ before the addition of $10^{-4} \mathrm{M}$ ABA or water and then incubated for an additional $48 \mathrm{hr}$. Cells were disrupted for protein extraction, and $\beta$-glucuronidase (GUS) activity was 
measured fluorometrically using the substrate 4-methylumbelliferyl $\beta$-D-glucuronide according to standard procedures (Jefferson et al., 1987). Transformation by microprojectile bombardment was performed according to Sawahel et al. (1992). For analysis of transient reporter gene expression, tissue was harvested immediately after bombardment, fragmented in a blender, and transferred onto cellophane-overlaid medium containing either $10^{-4} \mathrm{M} \mathrm{ABA}, 0.44 \mathrm{M}$ mannitol, or water. After $48 \mathrm{hr}$, tissue was homogenized by grinding with sand, and proteins were extracted for fluorometric analysis.

\section{Transgenic Moss}

Stably transformed plants expressing the npt/l gene as well as the Em-GUS fusion were selected and maintained on medium containing $50 \mu \mathrm{g} / \mathrm{mL}$ Geneticin (Sigma). Protonemal tissue was grown on cellophane-overlaid medium for 4 days before being transferred to medium containing $10^{-4} \mathrm{M} \mathrm{ABA}, 0.44 \mathrm{M}$ mannitol, or water for $24 \mathrm{hr}$. Proteins were extracted for fluorometric analysis of GUS activity as described previously in the text, or a solution containing the histochemical stain 5-bromo-4-chloro-3-indolyl $\beta$-D-glucuronide (Jefferson et al., 1987) was added to the undisturbed tissue. Stained cells were viewed by light microscopy after overnight incubation in darkness at $37^{\circ} \mathrm{C}$.

\section{Preparation of Nuclear Extract}

Nuclei were isolated by a modification of the method described by Watson and Thompson (1986). Approximately $30090-\mathrm{mm}$ Petri dish cultures yielded $250 \mathrm{~g}$ of moss tissue, which was ground with an equal weight of purified sand with a pestle and mortar for 3 to $5 \mathrm{~min}$. For each gram of tissue, $4 \mathrm{~mL}$ of buffer $\mathrm{A}(1 \mathrm{M}$ hexylene glycol, $10 \mathrm{mM}$ 3-[ $\mathrm{N}$-morpholino]propanesulfonic acid- $\mathrm{NaOH}, \mathrm{pH} 7.0,10 \mathrm{mM} \mathrm{MgCl}$, $0.5 \%[v / v]$ Triton X-100, $5 \mathrm{mM} \beta$-mercaptoethanol, $0.8 \mathrm{mM}$ phenylmethylsulfonyl fluoride [PMSF]) was added, mixed, and poured sequentially through 80 - and $45-\mu \mathrm{m}$ nylon meshes. The supernatant was centrifuged at $3000 \mathrm{~g}$ to sediment the nuclei, which were washed twice in 40 and $20 \mathrm{~mL}$ of buffer $\mathrm{B}$ (as given for buffer $\mathrm{A}$, except that $0.5 \mathrm{M}$ hexylene glycol was used). Nuclei were stained after each centrifugation with 4',6-diamidino-2-phenylindole ( $1 \mu \mathrm{g} / \mathrm{mL})$ and examined by fluorescence microscopy to determine their number and integrity. Hemocytometric analysis showed $\sim 25 \%$ recovery of nuclei.

Nuclear extracts were prepared by a modification of the method described by Parker and Topol (1984). Nuclei were gently resuspended in $15 \mathrm{~mL}$ of lysis buffer ( $110 \mathrm{mM} \mathrm{KCl}, 5 \mathrm{mM} \mathrm{MgCl}, 15 \mathrm{mM}$ Hepes- $\mathrm{KOH}$, $\mathrm{pH} 7.6,5 \mathrm{mM} \beta$-mercaptoethanol). Two milliliters of $2 \mathrm{M}\left(\mathrm{NH}_{4}\right)_{2} \mathrm{SO}_{4}$ was added dropwise with gentle mixing for $15 \mathrm{~min}$, and the mixture was transferred to Ti 70 centrifuge tubes (Beckman, High Wycombe, Bucks, UK). Chromatin and particulate material were sedimented by centrifugation at $40,000 \mathrm{rpm}$ for $75 \mathrm{~min}$. Proteins were precipitated by the addition of $0.3 \mathrm{~g} / \mathrm{mL}\left(\mathrm{NH}_{4}\right)_{2} \mathrm{SO}_{4}$ with stirring for $30 \mathrm{~min}$. The pellet was resuspended in $500 \mu \mathrm{L}$ of nuclear extraction buffer $(25 \mathrm{mM}$ Hepes$\mathrm{KOH}, \mathrm{pH} 7.6,40 \mathrm{mM} \mathrm{KCl}, 0.1 \mathrm{mM}$ EDTA, $10 \%$ [v/v] glycerol, $1 \mathrm{mM} \mathrm{DTT}$, $5 \mu \mathrm{g} / \mathrm{mL}$ antipain, $5 \mu \mathrm{g} / \mathrm{mL}$ leupeptin) and dialyzed for 3 to $4 \mathrm{hr}$ against nuclear extraction buffer without protease inhibitors and with $5 \mathrm{mM}$ $\beta$-mercaptoethanol substituted for DTT. Insoluble material was removed by centrifugation at $12,000 \mathrm{~g}$ for $10 \mathrm{~min}$. Extracts were frozen in aliquots in liquid nitrogen and stored at $-70^{\circ} \mathrm{C}$. Protein concentrations were estimated by measuring absorbance at $280 \mathrm{~nm}$ using BSA as the standard.

\section{Gel Retardation Assays}

The 75-bp wheat ABA-responsive element (ABRE)-containing fragment was released from plasmid pMG76.155 (Guiltinan et al., 1990) by digestion. Similarly, the mutant wheat $A B R E$-containing fragment was released from the plasmid pBM233.3. Both were end labeled with $\alpha-32$ P-dATP as described by Maniatis et al. (1982). DNA probes were purified by electrophoresis on a $6 \%(\mathrm{~W} / \mathrm{v})$ polyacrylamide gel and eluted in buffer ( $0.5 \mathrm{M}$ ammonium acetate, $0.1 \%$ [w/v] SDS, $10 \mathrm{mM}$ EDTA, $10 \mathrm{mM}$ magnesium acetate) at $37^{\circ} \mathrm{C}$ overnight followed by ethanol precipitation. Unlabeled wild-type and mutant competitor DNAs were isolated from $1.5 \%(\mathrm{w} / \mathrm{v})$ agarose gels by electroelution or by a Qiaex DNA gel extraction kit (Qiagen, Dorking, Surrey, UK).

Gel retardation assays were performed essentially as described by Guiltinan et al. (1990). Binding reaction mixtures $(20 \mu \mathrm{L})$ contained 10 to $15 \times 10^{3} \mathrm{cpm}$ of end-labeled DNA, $24 \mathrm{mM}$ Tris, $\mathrm{pH} 7.9,24 \%(\mathrm{v} / \mathrm{v})$ glycerol, $70 \mathrm{mM} \mathrm{KCl}, 0.14 \mathrm{mM}$ EDTA, $0.95 \mathrm{mM}$ PMSF, $2.15 \mathrm{mM}$ DTT, $15 \mathrm{mM} \mathrm{MgCl}_{2}, 500 \mathrm{ng}$ of poly(dl-dC), and competitor DNA as well as nuclear extracts as indicated in the legend to Figure $3 \mathrm{~A}$. The reactions were incubated at room temperature for 15 to $20 \mathrm{~min}$ and loaded onto a $6 \%$ (w/v) acrylamide native gel (40:1 acrylamide/bis-acrylamide, $2.5 \%$ [V/v] glycerol) before electrophoresis in $25 \mathrm{mM}$ Tris base, 190 $\mathrm{mM}$ glycine, $1 \mathrm{mM}$ EDTA, $\mathrm{pH} 8.3$, at $4^{\circ} \mathrm{C}$ with constant recirculation of the buffer. Gels were transferred to Whatman filter paper No. 3MM and dried for autoradiography at $-70^{\circ} \mathrm{C}$ overnight.

\section{DNase I Footprinting Analysis}

DNase I footprinting was performed by a modification of the method of Galas and Schmitz (1978). Reaction mixes $(20 \mu \mathrm{L})$ contained 10 to $15 \times 10 \mathrm{cpm}$ of singly end-labeled DNA fragments, $500 \mathrm{ng}$ poly(dl-dC), $24 \mathrm{mM}$ Tris, pH 7.9, 24\% (v/v) glycerol, $70 \mathrm{mM} \mathrm{KCl,} 0.14 \mathrm{mM}$ EDTA $0.95 \mathrm{mM}$ PMSF, $2.15 \mathrm{mM}$ DTT, and $15 \mathrm{mM} \mathrm{MgCl}_{2}$. Complexes were formed by the addition of 5 to $10 \mu \mathrm{g}$ of nuclear protein extract (or no protein in the control sample) to the DNA mix, which was then incubated for $20 \mathrm{~min}$ at room temperature. $\mathrm{CaCl}_{2}$ and $\mathrm{MgCl}_{2}$ were added to a final concentration of 0.4 and $0.2 \mathrm{mM}$, respectively. Four units of DNase I was added to each reaction, which were then incubated for $1 \mathrm{~min}$ at room temperature. Digestions were stopped by the addition of four volumes of DNase I stop solution (768 mM sodium acetate, $128 \mathrm{mM}$ EDTA, $0.56 \%[\mathrm{~W} / \mathrm{N}] \mathrm{SDS}, 256 \mu \mathrm{g} / \mathrm{mL}$ yeast tRNA) and immediately followed by the addition of an equal volume of phenol-chloroform. Following extraction, the DNA was precipitated in ethanol and electrophoresed in an $8 \%(\mathrm{~W} / \mathrm{V})$ acrylamide, $7 \mathrm{M}$ urea sequencing gel. DNA treated with the chemical sequencing $G+A$ reaction of Maxam and Gilbert (1980) was also run on the same gel. The gel was dried and autoradiographed, as described previously in Methods.

\section{ACKNOWLEDGMENTS}

We thank William Marcotte for providing the plasmids for this study. This work was funded in part by the European Communities BIOTECH Program as part of the EUROMOSS project of the Project of Technological Priority 1993-1996.

Received December 12, 1994; accepted March 2, 1995 


\section{REFERENCES}

Ashton, N.W., and Cove, D.J. (1977). The isolation and preliminary characterisation of auxotrophic mutants of the moss, Physcomitrella patens. Mol. Gen. Genet. 154, 87-95.

Bewley, J.D., and Oliver, M.J. (1992). Desiccation-tolerance in vegetative tissues and seeds: Protein synthesis in relation to desiccation and a potential role for protection and repair mechanisms. In Water and Life, G.N. Somero, C.B. Osmond, and C.L. Bolis, eds (Berlin: Springer-Verlag), pp. 141-160.

Bopp, M., and Werner, O. (1993). Abscisic acid and desiccationtolerance in mosses. Bot. Acta 106, 103-106.

Butler, W.M., and Cuming, A.C. (1993). Differential molecular responses to abscisic acid and osmotic stress in viviparous maize embryos. Planta 189, 47-54.

Chandler, P.M., and Robertson, M. (1994). Gene expression regulated by abscisic acid and its relation to stress tolerance. Annu. Rev. Plant Physiol. Plant Mol. Biol. 45, 113-141.

Close, T.J., Kortt, A.A., and Chandler, P.M. (1989). A cDNA-based comparison of dehydration-induced proteins (dehydrins) in barley and corn. Plant Mol. Biol. 13, 95-108.

Cove, D.J. (1992). Regulation of development in the moss Physcomitrella patens. In Development: The Molecular Genetic Approach, V.E. Russo, S. Brody, D. Cove, and S. Ottolenghi, eds (Berlin: SpringerVerlag), pp. 179-193.

Cove, D.J., and Knight, C.D. (1993). The moss Physcomitrella patens, a model system with potential for the study of plant reproduction. Plant Cell 5, 1483-1488.

Devos, K.M., Atkinson, M.D., Chinoy, C.N., Guiltinan, M.J., Quatrano, R.S., and Gale, M.D. (1991). Chromosomal location and variability in wheat, barley and rye of a wheat gene encoding a b-Zip protein. Theor. Appl. Genet. 82, 665-667.

Dure, L.S., III, Crouch, M.L., Harada, J., Ho, T.-H.D., Mundy, J.C., Quatrano, R.S., Thomas, T., and Sung, Z.R. (1989). Common amino acid sequence domains among the LEA proteins of higher plants. Plant Mol. Biol. 12, 475-486.

Galas, D.J., and Schmitz, A. (1978). DNase footprinting: A simple method for the detection of protein-DNA binding specificity. Nucleic Acids Res. 5, 3157-3170.

Garner, D., and Paollilo, D.J. (1973). On the functioning of stomates in Funaria. Bryologist 76, 423-427.

Goode, J.A., Stead, A.D., and Duckett, J.G. (1992). Redifferentiation of moss protonemata-An experimental and immunofluorescence study of brood cell formation. Can. J. Bot. 71, 1510-1519.

Grimsley, N.H., Ashton, N.W., and Cove, D.J. (1977). The production of somatic hybrids by protoplast fusion in the moss Physcomitrella patens. Mol. Gen. Genet. 154, 97-100.

Guiltinan, M.J., Marcotte, W.R., Jr., and Quatrano, R.S. (1990). A plant leucine zipper protein that recognizes an abscisic acid response element. Science 250, 267-271.

Jacobsen, J.V., and Shaw, D.C. (1989). Heat-stable proteins and abscisic acid action in barley aleurone cells. Plant Physiol. 91, 1520-1526.

Jefferson, R.A., Kavanagh, T.A., and Bevan, M.W. (1987). GUSfusions: $\beta$-Glucuronidase as a sensitive and versatile gene fusion marker in higher plants. EMBO J. 6, 3901-3907.
Knight, C.D. (1994). Studying plant development in mosses: The transgenic route. Plant Cell Environ. 17, 669-674.

Maniatis, T., Fritsch, E.F., and Sambrook, J. (1982). Molecular Cloning: A Laboratory Manual. (Cold Spring Harbor, NY: Cold Spring Harbor Laboratory Press).

Marcotte, W.R., Jr., Bayley, C.C., and Quatrano, R.S. (1988). Regulation of a wheat promoter by abscisic acid in rice protoplasts. Nature 335, 454-457.

Marcotte, W.R., Jr., Russell, S.H., and Quatrano, R.S. (1989). Abscisic acid-responsive sequences from the $\mathrm{Em}$ gene of wheat. Plant Cell 1, 969-976.

Maxam, A.M., and Gilbert, W. (1980). Sequencing end-labeled DNA with base-specific chemical cleavages. Methods Enzymol. 65, 499-560.

Morris, P.C., Kumar, A., Bowles, D.J., and Cuming, A.C. (1990). Osmotic stress and abscisic acid regulate expression of the wheat $E m$ genes. Eur. J. Biochem. 190, 625-630.

Oliver, M.J. (1991). Influence of protoplasmic water loss on the control of protein synthesis in the desiccation-tolerant moss Tortula ruralis: Ramifications for a repair-based mechanism of desiccation tolerance. Plant Physiol. 97, 1501-1511.

Parker, C.S., and Topol, J. (1984). A Drosophila RNA polymerase II transcription factor contains a promoter-region-specific DNA-binding activity. Cell 36, 357-369.

Paskowski, J., Baur, M., Bogucki, A., and Potrykus, I. (1988). Gene targetting in plants. EMBO. J. 7, 4021-4026.

Piatkowski, D., Schneider, K., Salamini, F., and Bartels, D. (1990). Characterization of five abscisic acid-responsive cDNA clones isolated from the desiccation-tolerant plant Craterostigma plantagineum and their relationship to other water-stress genes. Plant Physiol. 94, 1682-1688.

Robertson, M., and Chandler, P.M. (1992). Pea dehydrins: Identification, characterisation and expression. Plant Mol. Biol. 19, 1031-1044.

Rock, C., and Quatrano, R.S. (1994). Insensitivity is in the genes. Curr. Biol. 4, 1013-1015.

Rock, C., and Quatrano, R.S. (1995). The role of hormones during seed development. In Plant Hormones: Physiology, Biochemistry and Molecular Biology, P. Davies, ed (Dordrecht, The Netherlands: Kluwer Academic Publishers), pp. 671-697.

Russell, A.J. (1993). Morphogenesis in the Moss Physcomitrella patens. PhD Dissertation (Leeds, UK: University of Leeds).

Sambrook, J., Fritsch, E.F., and Maniatis, T. (1989). Molecular Cloning: A Laboratory Manual, 2nd ed. (Cold Spring Harbor, NY: Cold Spring Harbor Laboratory Press).

Sawahel, W., Onde, S., Knight, C.D., and Cove, D.J. (1992). Transfer of foreign DNA into Physcomitrella patens protonemal tissue by using the gene gun. Plant Mol. Biol. Rep. 10, 315-316.

Schaefer, D., Zryd, J.-P., Knight, C.D., and Cove, D.J. (1991). Stable transformation of the moss Physcomitrella patens. Mol. Gen. Genet. 226, 418-424.

Scott, H.B., II, and Oliver, M.J. (1994). Accumulation and polysomal recruitment of transcripts in response to desiccation and rehydration of the moss Tortula ruralis. J. Exp. Bot. 274, 577-583.

Sehgal, A. (1994). Promoter Structure and Function in the Moss Physcomitrella patens. PhD Dissertation (Leeds, UK: University of Leeds). 
Skriver, K., and Mundy, J. (1990). Gene expression in response to abscisic acid and osmotic stress. Plant Cell 2, 503-512.

Watson, J.C., and Thompson, W.F. (1986). Purification and restriction endonuclease analysis of plant nuclear DNA. Methods Enzymol. $118,57-75$.
Werner, O., and Bopp, M. (1993). The influence of ABA and IAA on in vivo phosphorylation of proteins in Funaria hygrometrica Hedw. J. Plant Physiol. 141, 93-97.

Werner, O., Ros Espin, R.M., Bopp, M., and Atzorn, R. (1991) Abscisic-acid-induced drought tolerance in Funaria hygrometrica Hedw. Planta 186, 99-103. 
Molecular Responses to Abscisic Acid and Stress Are Conserved between Moss and Cereals. C. D. Knight, A. Sehgal, K. Atwal, J. C. Wallace, D. J. Cove, D. Coates, R. S. Quatrano, S. Bahadur, P. G. Stockley and A. C. Cuming

Plant Cell 1995;7;499-506

DOI 10.1105/tpc.7.5.499

This information is current as of July 22, 2020

Permissions

eTOCs

CiteTrack Alerts

Subscription Information
https://www.copyright.com/ccc/openurl.do?sid=pd_hw1532298X\&issn=1532298X\&WT.mc_id=pd_hw1532298X

Sign up for eTOCs at:

http://www.plantcell.org/cgi/alerts/ctmain

Sign up for CiteTrack Alerts at:

http://www.plantcell.org/cgi/alerts/ctmain

Subscription Information for The Plant Cell and Plant Physiology is available at: http://www.aspb.org/publications/subscriptions.cfm

\section{(C) American Society of Plant Biologists}

